\title{
Use of $\mathrm{KOH}$ in IBA dissolution and substrate formulation in the rooting of Acer palmatum Thunb. cuttings
}

El uso de KOH en la disolución de IBA y formulación de sustratos para el enraizamiento de esquejes de Acer palmatum Thunb.

\author{
Paim, L.P. ${ }^{1 *}$; Avrella, E.D. ${ }^{1}$; Caumo, M. ${ }^{1}$; Fior, C.S. ${ }^{1}$ \\ ${ }^{1}$ Federal University of Rio Grande do Sul, Departament of Horticulture and Forestry, \\ Porto Alegre, Rio Grande do Sul, Brazil. \\ lucianappaim@bol.com.br; dudademari@hotmail.com; caumonique@gmail.com; csfior@ufrgs.br
}




\section{Summary}

Acer palmatum is a species widely used in landscaping in southern Brazil. It has some limitations in propagation via seeds, therefore, cutting is a viable propagation method, especially when plant regulators and plant substrates are properly. The objective was to evaluate substrate and solvent compositions for indolebutyric acid (IBA) dissolution in the rooting of Acer palmatum cuttings. Apical herbaceous cuttings were used and inserted for five seconds in IBA solution $\left(8 \mathrm{~g} \mathrm{~L}^{-1}\right)$ diluted in hydroalcoholic solvents $(50 \%)$ and potassium hydroxide $(0.5 \mathrm{M} \mathrm{KOH})$. Then, they were established in multicellular trays with substrates carbonized rice husk (CRH) and expanded clay (EXCL), isolates and in mixtures $(1: 1 ; 2: 1$ and 1:2, $\mathrm{v} / \mathrm{v}$ ). The experimental design was completely randomized in a $2 \times 5$ bifactorial scheme (forms of dissolution of IBA x substrates), in four replications of 10 cuttings. The results showed no interaction between the factors. However, the dissolution of IBA in KOH and the substrates CRH and EXCL (1:2 and 2:1, v/v) provided higher rooting and leaf retention. In addition, the substrates showed greater root dry mass and aerial part for cutting development. Therefore, vegetative propagation of Acer palmatum through cuttings is more appropriate with the dissolution of IBA with $\mathrm{KOH}$ solvent $(66,84 \%$ rooting) and formulated substrates CRH and EXCL (1:2 and 2:1, v/v) (66,87\% rooting).

Keywords: cutting, plant growth regulator; potassium hydroxide; Sapindaceae; vegetative propagation.

\section{Resumen}

Acer palmatum es una especie muy utilizada en jardinería en el sur de Brasil. Tiene algunas limitaciones en la propagación através de semillas, por lo tanto, esqueje es un método de propagación viable, especialmente cuando los reguladores del crecimiento de las plantas y los sustratos de las plantas son los adecuados. El objetivo fue evaluar la composición del sustrato y solvente para la disolución del ácido indolbutírico (IBA) en el enraizamiento de esquejes de Acer palmatum. Se utilizaron esquejes herbáceos apicales que se insertaron durante cinco segundos en solución de IBA $\left(8 \mathrm{~g} \mathrm{~L}^{-1}\right)$ diluida en solventes hidroalcohólicos (50\%) e hidróxido de potasio (KOH $0.5 \mathrm{M})$. Luego, se establecieron en bandejas multicelulares con sustratos de cáscara de arroz carbonizada (CAC) y arcilla expandida (AE), aislados y en mezclas (1:1; 2:1 y 1:2, $\mathrm{v} / \mathrm{v}$ ). El diseño experimental fue completamente al azar en un esquema bifactorial 2 x 5 (formas de disolución de IBA x sustratos), en cuatro repeticiones de 10 esquejes. Los resultados no mostraron interacción entre los factores. Sin embargo, la disolución de IBA en $\mathrm{KOH}$ y los sustratos CAC y AE (1:2 y 2:1, v/v) proporcionaron mayor enraizamiento y retención de hojas. Además, los sustratos mostraron mayor masa seca de raíz y parte aérea para el desarrollo del esqueje. Por tanto, la propagación vegetativa de Acer palmatum através de esquejes es más apropiada con la disolución de IBA con solvente $\mathrm{KOH}(66,84 \%$ de enraizamiento) y sustratos formulados CAC y AE (1:2 y 2:1, v/v) (66,87\% enraizamiento).

Palabras clave: corte, regulador del crecimiento vegetal; hidróxido de potasio; Sapindaceae; propagación vegetativa. 


\section{Introduction}

There is a growing demand for seedlings of plant species that have potential for use in the restoration of degraded areas, in addition to characteristics that allow their economic exploitation, such as, for example, in the ornamentation and landscaping of external spaces. Allied to this, the search for methodologies for the production of quality seedlings, with low cost and adequate performance after removal from the nursery (Mews et al., 2015), which has been one of the major limitations during driving and multiplication of plants.

However, some species have very low seed production, in addition to barriers that can hamper their germination, such as intense consumption by fauna, the presence of dormancy mechanisms, among others. Cutting is a widely used asexual propagation method based on the insertion of a particular plant segment, such as branches, roots or leaves, into a suitable medium (substrate), resulting in the production of adventitious roots. These roots originate because plant cells have the ability to revert their differentiated state and return to the meristematic condition, so they are able to originate other organs (Hartmann et al., 2011). The success of rooting depends on some external factors, such as the substrate, which must provide support to the cuttings and maintain an appropriate balance between water retention and the aeration space. It is an easily manipulated component and available in several options, so that each has different physical and chemical characteristics. In relation to the cuttings, it is desirable that the substrates have high macroporosity, in order to promote aeration of the root system, and the rooting of the propagative material (Zorzeto et al., 2014).

Although it is a simple and inexpensive technique, not all species can be propagated through cutting, mainly because of their low rooting capacity. In these cases, the use of plant growth regulator enables the successful propagation of some species, assisting in the formation of adventitious roots (Emer et al., 2019). Several compounds can be used, the main ones being synthetic auxins, such as indolbutyric acid (IBA) and naphthalene acetic acid (NAA), in addition to natural auxins, such as indole acetic acid (IAA) (Souza et al., 2018).

IBA requires dissolution in small quantities and in a certain compound, which may be alcohol, sodium or potassium hydroxide, among others (Fachinello et al., 2005). Hydroalcoholic solutions are commonly used for their practicality, however prolonged exposure or high concentrations may cause phytotoxic effects as well as precipitation of IBA. Nevertheless, such effect is not observed when using potassium hydroxide $(\mathrm{KOH})$, the use of which is less frequent but not less effective (Fachine1 lo et al., 2005). Some studies demonstrate the performance of using different solvents, so that responses are dependent on each species (Yamamoto et al., 2010; Stulzer et al., 2018).

Popularly known as Japanese maple or palmate maple, Acer palmatum Thunb. is a species in the Sapindaceae family widely used for ornamentation in the world. It is native to Asia, a 6-8 $\mathrm{m}$ tall deciduous tree, dense canopy, upright inflorescences composed of purplish flowers and samara-like fruits. The palmate leaves with serrated edges acquire intense yellow-to-red color during the autumn-winter period, thus demonstrating their high ornamental potential (Lorenzi et al., 2018). 
The seed-propagation of the species has the need of long stratification periods to overcome their dormancy (Toth and Garret, 1989). Because of this limitation, there is a need for studies that investigate new ways of propagating the species (Stuepp et al., 2016). One way to overcome such issue is the vegetative propagation by cuttings, which has numerous advantages, such as allowing large-scale propagation from propagating material from a few, or even a single, matrix plant in shortterm and low cost, simple execution and high uniformity of seedlings (Fachinello et al., 2005). Some techniques have already been used to vegetatively propagate the species of $A$. palmatum, such as herbaceous cuttings and mini-cuttings (Emer et al., 2016; Stuepp et al., 2016).

Based on this, knowledge about the proper substrate formulation is extremely important during the rooting process from cuttings, coupled with this, the phytoregulator when diluted in an appropriate solvent can influence the performance of this hormone, consequently, the relationship of these factors implies in a positive way in the development of the cuttings root system. Thus, the objective of this study was to test the effect of different substrate and solvent compositions for the dissolution of indolebutyric acid (AIB) on the rooting of Acer palmatum Thunb. cuttings in order to optimize the production of clonal seedlings of the species.

\section{Material and Methods}

The experiment was conducted in a protected environment belonging to the Department of Horticulture and Forestry, located at the Faculty of Agronomy of the Federal University of Rio Grande do Sul (UFRGS), in Porto Alegre, state of Rio Grande do Sul, Brazil.

A completely randomized design in a $2 \times 5$ bifactorial scheme was used, with four replications of 10 cuttings each, 40 per treatment, totaling 400 cuttings. The first factor consisted of the forms of dissolution of IBA (hydroalcoholic solution $50 \%$ and potassium hydroxide solution $-2 \mathrm{~mL}$ of 0.5 molar $\mathrm{KOH}$ in $100 \mathrm{~mL}$ of water), and the second factor consisted of the substrate formulations: carbonized rice husk $(\mathrm{CRH})$, and expanded clay (EXCL $-7 \mathrm{~mm}$ in particle size), CRH + EXCL (1:1, $\mathrm{v} / \mathrm{v}), \mathrm{CRH}+\operatorname{EXCL}(2: 1, \mathrm{v} / \mathrm{v})$ and $\mathrm{CRH}+\operatorname{EXCL}(1: 2, \mathrm{v} / \mathrm{v})$. The expanded clay used is a light aggregate of expansive clay known internationally as LECA (Light Expanded Clay Aggregates), its grains can be whole or broken, consisting of a rigid and highly resistant microporous surface, with the interior formed by a ceramic mass porous. Such materials were chosen due to their physical characteristics of high total porosity and low water holding capacity (Tab. 1).

Firstly, the herbaceous cuttings were collected from an adult mother-plant at about $6 \mathrm{~m}$ high and 30 years old, located on the facilities of the college, in October 2018. Thereby, only the apexes of the branches were used in the preparation of cuttings (Fig. 1). They were standardized with $10 \mathrm{~cm}$ in length from the insertion of the first leaves, maintaining four fully expanded apical leaves, where the two youngest leaves had their limbs reduced by half, because they transpire more than older leaves. At the basal end of each cutting, a bevel cut was made. During this process, the cut- 
tings were kept in containers with water for approximately 10 minutes and afterwards they were immersed in solutions of indolebutyric acid (IBA), and the immersion in water was intended to reduce the effect of possible oxidation and dehydration.

The cuttings were inserted in $8 \mathrm{~g} \mathrm{~L}^{-1}$ IBA solution for five seconds. The phytoregulator was diluted in two ways in hydroalcoholic solution $(50 \%)$ and potassium hydroxide solution $(\mathrm{KOH})(2 \mathrm{~mL}$ of $\mathrm{KOH}$ in $100 \mathrm{~mL}$ of water $)$. After immersion, the cuttings were immediately transferred to multicellular polyethylene trays with 50 cavities and a cell volume of $121 \mathrm{~cm}$, which were filled with different substrate formulations.

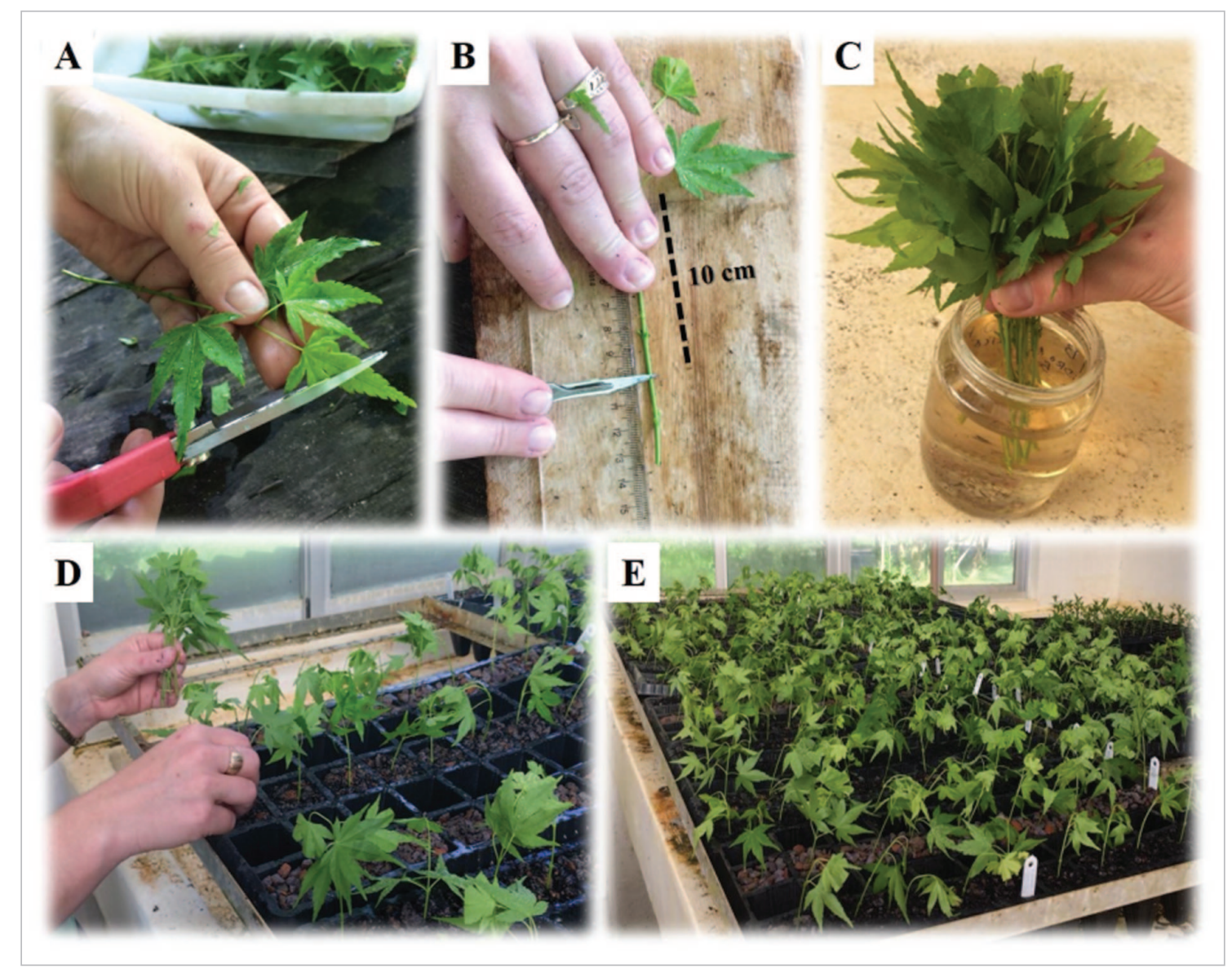

Figure 1. Sequence diagram of the preparation of Acer palmatum species herbaceous cuttings: cutting with four apical leaves, removing half of their limbs (A), 10-cm standardized cutting and bevel cut (B), cuttings arrangement in IBA solution (C), the planting of the cuttings in substrate (D) and an overview of the cuttings after planting, packed in the nebulization with controlled intermittent system (E).

The cuttings had their bases inserted into the substrates about $1 \mathrm{~cm}$ deep and kept on mist irrigation (relative humidity above $90 \%$ ), with an intermittent timer-controlled system of 15 seconds every 5 minutes during the day, and for 10 seconds every 50 minutes during night, which remained under averages of luminous radiation and temperature of $50 \%$ and $21,7^{\circ} \mathrm{C}$, respectively. 
The substrates were physically and chemically characterized through analyses performed at the Substrate Analysis Laboratory of the Faculty of Agronomy at UFRGS. The chemical analyses considered the electrical conductivity (EC) and hydrogen potential $(\mathrm{pH})$ evaluations, in a 1:5 substrate: water dissolution $(\mathrm{v} / \mathrm{v})$, according to IN no. 17 of May 21, 2007, which establishes methods for analysis of plant substrates (MAPA, 2007).

For the physical attribute relative to substrate density, dry density (DD) was evaluated through the self-compaction method (Hoffmann, 1970). Determinations of total porosity (TP), aeration space (AS), available water (AW), easily available water $(\mathrm{EAW})$, buffering water $(\mathrm{BW})$, remaining water $(\mathrm{RW})$, and water retention capacity (WRC) were obtained at $0,10,50$ and $100 \mathrm{hPa}$ voltages, using voltage funnels, according to the principles of De Boodt and Verdonck (1972). Particle size distribution was determined using 100-g samples of air-dried material, where the samples were placed on a sieve set and kept under stirring for two minutes. The fractions retained in each sieve were weighed and the percentages on the total weight of the samples were calculated (Tab.1).

Table 1. Chemical, physical and particle size characterization of carbonized rice husk $(\mathrm{CRH})$ and expanded clay (EXCL) materials and their mixtures in 1:1, 2:1 and 1:2 volumetric proportions.

\begin{tabular}{|c|c|c|c|c|c|}
\hline & $\mathrm{CRH}$ & EXCL & $\begin{array}{c}\text { CRH + EXCL } \\
(1: 1, \mathrm{v} / \mathrm{v})\end{array}$ & $\begin{array}{c}\text { CRH + EXCL } \\
(2: 1, \mathrm{v} / \mathrm{v})\end{array}$ & $\begin{array}{c}C R H+E X C L \\
(1: 2, v / v)\end{array}$ \\
\hline \multicolumn{6}{|c|}{ Physical properties } \\
\hline $\mathrm{DD}\left(\mathrm{kg} \mathrm{m}^{-3}\right)$ & 145.06 & 357.11 & 284.01 & 275.69 & 330.64 \\
\hline $\mathrm{CH}(\%)$ & 50.56 & 21.56 & 33.28 & 51.21 & 33.36 \\
\hline ТР (\%) & 85.40 & 55.87 & 61.23 & 70.35 & 58.23 \\
\hline AS (\%) & 67.72 & 42.10 & 43.94 & 47.69 & 40.71 \\
\hline AW (\%) & 8.45 & 2.88 & 6.79 & 10.68 & 7.24 \\
\hline EAW (\%) & 7.68 & 2.72 & 5.90 & 9.34 & 6.07 \\
\hline $\mathrm{BW}(\%)$ & 0.78 & 0.16 & 0.89 & 1.34 & 1.17 \\
\hline RW (\%) & 9.22 & 10.90 & 10.50 & 11.98 & 10.28 \\
\hline \multicolumn{6}{|c|}{ Chemical properties } \\
\hline $\mathrm{EC}\left(\mathrm{mS} \mathrm{cm}{ }^{-1}\right)$ & 0.07 & 0.02 & 0.08 & 0.10 & 0.05 \\
\hline $\mathrm{pH}\left(\mathrm{H}^{2} \mathrm{O}\right)$ & 7.63 & 6.32 & 7.17 & 7.35 & 7.41 \\
\hline \multicolumn{6}{|c|}{ Particle size distribution (\%) } \\
\hline$>3.35 \mathrm{~mm}$ & 3.88 & 89.18 & 69.70 & 84.43 & 80.57 \\
\hline $3.35-2.00 \mathrm{~mm}$ & 42.49 & 10.51 & 29.59 & 15.43 & 19.03 \\
\hline $2.00-1.40 \mathrm{~mm}$ & 28.53 & 0.27 & 0.65 & 0.13 & 0.32 \\
\hline $1.40-0.50 \mathrm{~mm}$ & 24.60 & 0.04 & 0.06 & 0.01 & 0.08 \\
\hline $0.50-0.106 \mathrm{~mm}$ & 0.50 & 0.00 & 0.00 & 0.00 & 0.00 \\
\hline$<0.106 \mathrm{~mm}$ & 0.00 & 0.00 & 0.00 & 0.00 & 0.00 \\
\hline
\end{tabular}

$\mathrm{DD}=$ dry density $\mathrm{CH}=$ current humidity; $\mathrm{TP}=$ total porosity; $\mathrm{AS}=$ aeration space; $\mathrm{AW}=$ available water; $\mathrm{EAW}=$ easily available water; $\mathrm{BW}=$ buffering water; $\mathrm{AR}=$ remaining water; $\mathrm{EC}=$ electrical conductivity. 
At the end of the experiment, at 60 days after installation, the percentages of cutting survival, rooting, leaf retention, root volume (in $\mathrm{mL}$ ), dry weight of the aerial part $(\mathrm{g})$ and root system (g) were evaluated. Leaf retention was evaluated by counting the number of leaves that remained in the cuttings after the experiment period, and its percentage was calculated in relation to the initial number of leaves. Survival was performed by counting, after which the percentage was calculated based on the initial number of cuttings within each repetition.

Root volume $(\mathrm{mL})$ was determined by detaching the root system from the aerial part, followed by measuring the difference in volume obtained in a graduated beaker, and calculating the value per rooted cutting. Root dry mass was also calculated through rooted cuttings, and dry mass of the aerial part was obtained by the surviving cuttings. Dry mass was obtained by the percentage difference in mass after constant weight in an oven at $65^{\circ} \mathrm{C}$.

The data were subjected to the assumptions of the analysis of variance by the Bartlett and Kolmogorov-Smirnov tests, with the aerial part dry mass data being transformed to $\frac{x}{5}$. After fulfilling the assumptions of the analysis of variance (ANOVA), a simple statistical model was used, in which the ANOVA was performed in a bifactorial scheme, testing the interaction between the factors, followed by comparison of means by the Fisher LSD test. (least significant difference) at the level of $5 \%$ probability of error, using Costat 6.4 software.

\section{Results}

The results showed that there was no interaction between substrates and IBA dissolution forms for all analyzed variables. However, substrate formulations influenced the rooting percentage, leaf retention and dry mass of the aerial part and root system, while the dissolution forms influenced only the rooting percentage and leaf retention (Tab. 2).

Table 2. Analysis of variance of Acer palmatum herbaceous cuttings treated with indolebutyric acid (IBA) and established in different substrate formulations.

\begin{tabular}{|c|c|c|c|c|c|}
\hline & $\begin{array}{c}\text { IBA } \\
\text { Dissolution }\end{array}$ & Substrate & Interaction & $\begin{array}{l}\text { Overall } \\
\text { average }\end{array}$ & $\begin{array}{c}\text { Standard } \\
\text { error }\end{array}$ \\
\hline Survival (\%) & $0.2504^{\mathrm{ns}}$ & $0.8744^{\mathrm{ns}}$ & $0.3861^{\mathrm{ns}}$ & 98.47 & 0.7343 \\
\hline Rooting (\%) & $<0.001$ & $<0.001$ & $0.0998^{\text {ns }}$ & 55.64 & 3.4027 \\
\hline Leaf retention $(\%)$ & 0.0321 & 0.0196 & $0.9283^{\text {ns }}$ & 85.44 & 2.1171 \\
\hline Root volume/cutting (mL) & $0.3529^{\mathrm{ns}}$ & $0.2224^{\text {ns }}$ & $0.5739^{\mathrm{ns}}$ & 0.27 & 0.0191 \\
\hline DWAP/cutting (g) & $0.4379^{\text {ns }}$ & 0.0344 & $0.0537^{\mathrm{ns}}$ & 0.19 & 0.0054 \\
\hline DWRS/cutting (g) & $0.8641^{\mathrm{ns}}$ & 0.0232 & $0.1518^{\mathrm{ns}}$ & 0.03 & 0.0027 \\
\hline
\end{tabular}

DWAP $=$ dry weight of the aerial part; DWRS $=$ dry weight of the root system. ${ }^{\text {ns }}=$ not significant at $5 \%$ probability of error. 
Indolebutyric acid diluted in potassium hydroxide $(\mathrm{KOH})$ solution showed superiority in the results with mean values of $66.84 \%$ and $89.82 \%$ for rooting and leaf retention, respectively (Fig. 2). However, for percentage of survival, root volume per cutting, aerial part and root dry mass, no significant differences were found between IBA dissolutions, presenting average values of $98.46 \%, 0.28 \mathrm{~mL} /$ cutting, 0.19 $\mathrm{g} /$ cutting and $0.032 \mathrm{~g} /$ cutting, respectively.

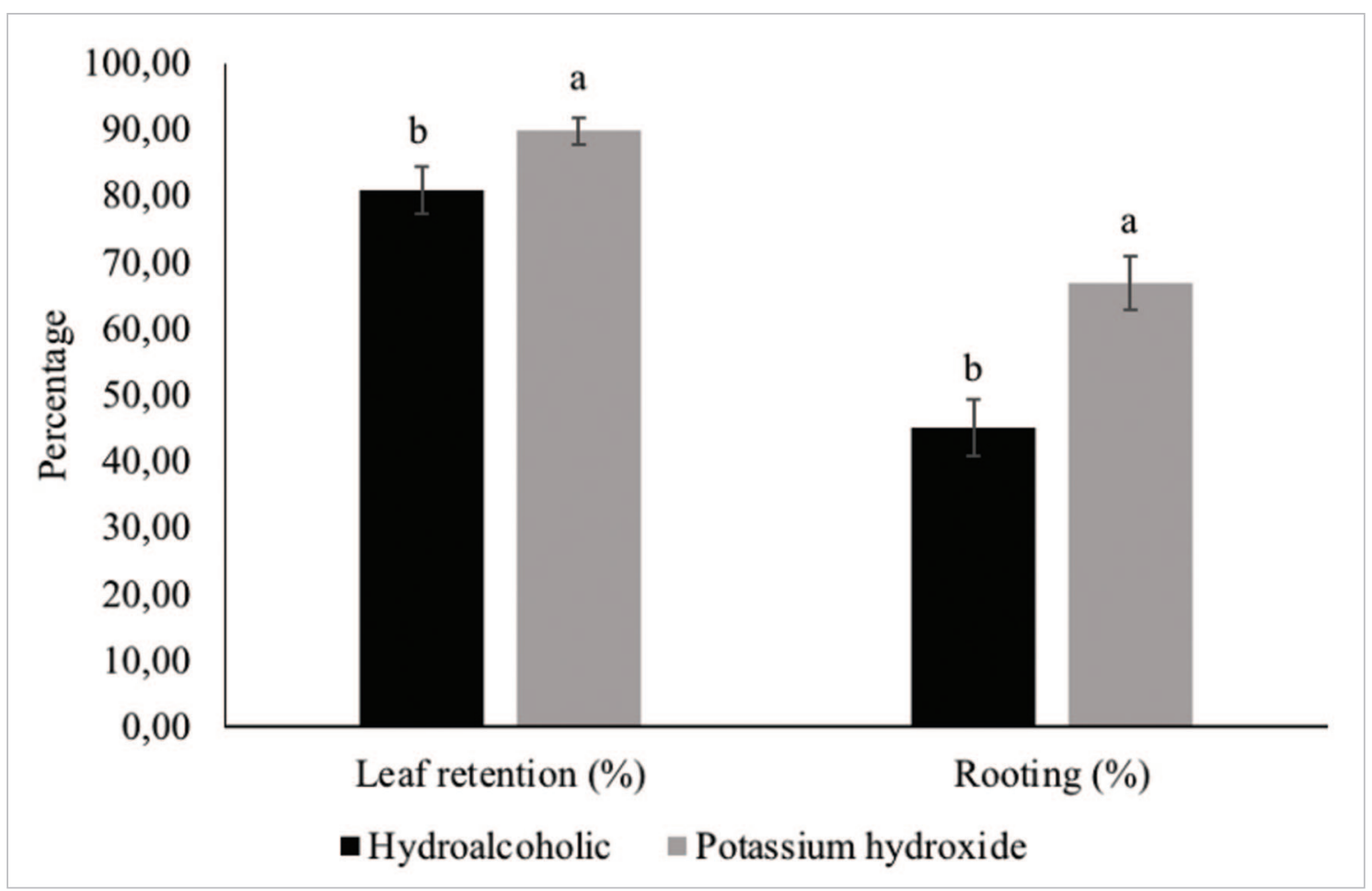

Figure 2. Leaft retention (\%) and rooting (\%) of Acer palmatum herbaceous cuttings treated with indolebutyric acid (IBA) diluted in potassium hydroxide solution $(\mathrm{KOH})$ and hydroalcoholic solution (ethanol + water 1:1 ratio). Means followed by the same letter between the dilution forms do not differ from each other by the DMS test at $5 \%$ probability of error.

Regarding the substrates used for the development of $A$. palmatum herbaceous cuttings, no influence of the tested formulations was observed on survival percentage (98.47) and root volume per cutting (0.27). Despite this, it can be verified that the mixture of carbonized rice hull and expanded clay, in volumetric proportions of $1: 2(\mathrm{v} / \mathrm{v})$, provided satisfactory results of rooting percentage and root dry mass (Fig. 3 and 4).

The solely use of substrate carbonized rice husk showed highest values of to the percentage of leaf retention and dry mass of aerial part. Moreover, this last variable also excelled in the formulation of carbonized rice husk and expanded clay $(2: 1$, v/v) (Fig. 3 and 4). 


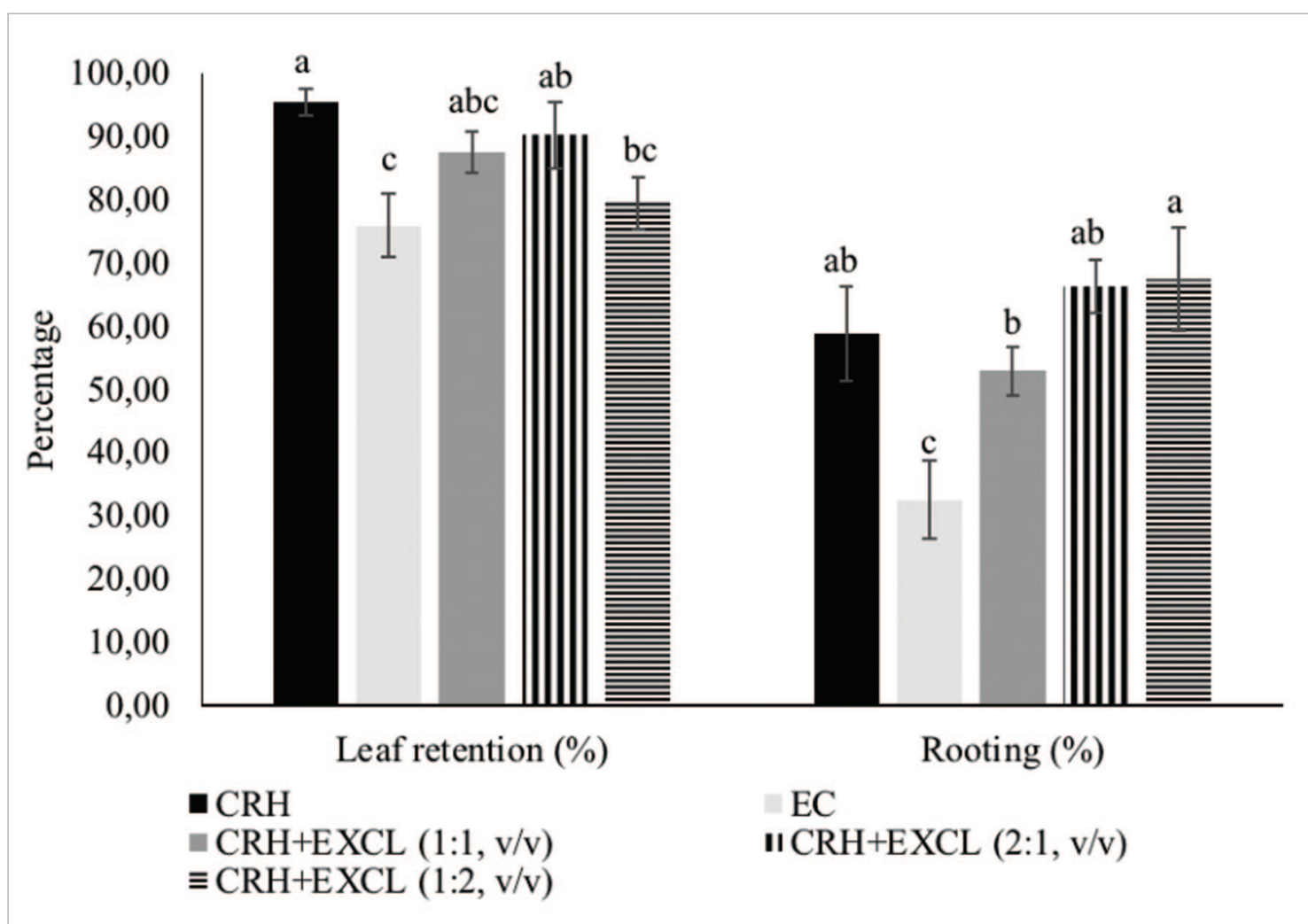

Figure 3. Leaft retention (\%) and rooting (\%) of Acer palmatum herbaceous cuttings established in different substrate formulations. Means followed by the same letter between the substrates do not differ from each other by the DMS test at 5\% probability of error. $\mathrm{CHR}=$ carbonized rice husk; EXCL $=$ expanded clay.

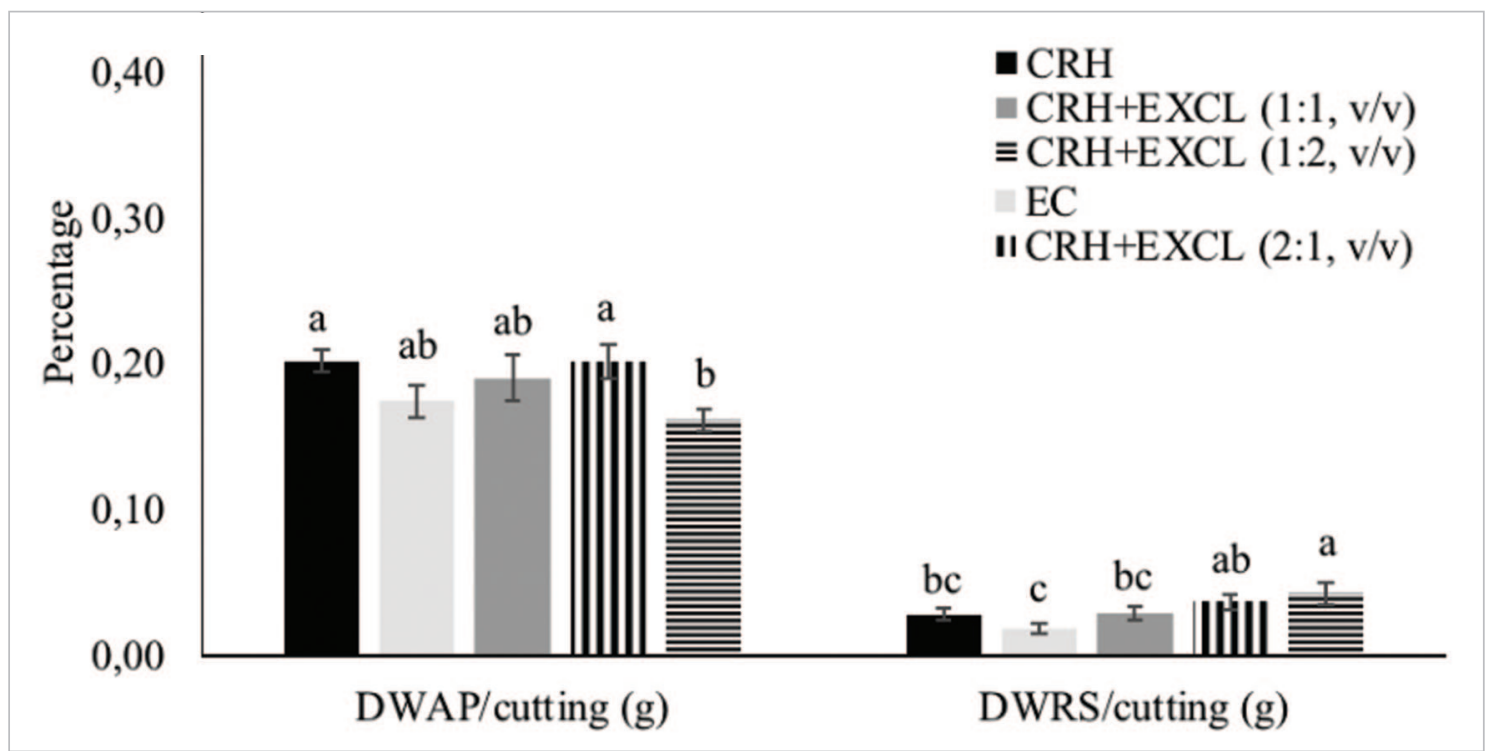

Figure 4. Dry mass of the aerial part and root system of Acer palmatum herbaceous cuttings established in different substrate formulations. Means followed by the same letter between the substrates do not differ from each other by the DMS test at $5 \%$ probability of error. CHR = carbonized rice husk; EXCL $=$ expanded clay. 


\section{Discusión}

The cutting technique is a type of vegetative propagation of high importance in the cultivation of several species. It is a simple, fast and low-cost methodology, favoring not only the uniform production of a large number of branches in small spaces, but also maintains the genetic characteristics of the donor plant (Hartmann et al., 2011). The cutting method is promising for large-scale A. palmatum seedling production (Emer et al., 2016), t. In addition, Stuepp et al. (2016) found superior rooting results for this species through the use of vegetative propagation from minicuttings.

The use of synthetic auxins such as indolebutyric acid may increase the rate of rooted cuttings, number of roots and rooting uniformity of most species (Hartmann et al., 2011). However, the use of chemicals to dissolve growth regulators may not allow the complete dissolution of IBA at low concentrations, while at high concentrations, they may kill the base tissue of cuttings, impairing the rooting process (Oliveira et al., 2009). According to the results of this study, the use of $\mathrm{KOH}$ in IBA dissolution allowed a higher percentage of rooting and leaf retention in A. palmatum cuttings, in comparison to the hydroalcoholic solution.

The higher rooting of cuttings obtained with the $\mathrm{KOH}$ solution allows us to infer that the use of hydroalcoholic solution ( $50 \%$ ethanol) may have caused damage to the base cells of the cuttings, which are responsible for the emission of root primordia through rhizogenesis. However, it is inferred that if the cuttings immersion time is shortened, there may be a decrease in the toxicity effect. In this context, the adequate choice of solvent for auxin dissolution favors root multiplication and cellular elongation, providing a dense and accelerated rooting during seedling production (Botin and Carvalho, 2015).

In addition to the root system variables, a positive effect on leaf retention can be observed with the use of $\mathrm{KOH}$ in the dissolution of IBA, that is, the higher leaf retention may have been due to the greater rooting of cuttings in this treatment, showing that these variables are dependent on each other, therefore the root development is directly related to the growth of the aerial part.

The effect of hydroalcoholic solution on rooting and leaf system of A. palmatum cuttings may have provided the synthesis of phenolic compounds by leaves (Vignolo et al., 2014). The over production of phenolic compounds causes oxidative stress in plant tissues, and ethanol is one of the enhancers of the formation of these compounds (Vaccari et al., 2009). In this context, ethanol is a product that presents high phytotoxicity, that is, the more tender the plant tissue, the easier it will be damaged, which may result in tissue dehydration (Mahmoud and Al-Ani, 2016). Thus, even though some authors suggest the dissolution of IBA in ethanol, mainly due to its ease of preparation, in this study, A. palmatum cuttings treated with the $\mathrm{KOH}$ phytoregulator solution presented a higher percentage of rooting and leaf retention in comparison to hydroalcoholic solution.

In addition to determining the most appropriate form of indolebutyric acid dissolution, substrate formulation was also a factor that influenced the results with $A$. palmatum cuttings (Tab. 2). Suitable substrates contribute to the formation of the 
root system by allowing an adequate supply of oxygen and water (Kratz et al., 2012) at the base of the stem for root development (Hartmann et al., 2011).

The mixing of components in the composition of a substrate enables complementarity, resulting in adequate physical and chemical characteristics compared to the use of pure materials (Simões et al., 2012). In this sense, the elevated rooting percentage $(67.5 \%)$ and root dry mass production $(0.044 \mathrm{~g})$ in A. palmatum cuttings were obtained using the mixture of carbonized rice husk and expanded clay $(1: 2$, $\mathrm{v} / \mathrm{v})$. Regarding the dry matter production of the aerial part, satisfactory results were found with the use of the same components in the mixtures, only in the volumetric proportion of $2: 1(\mathrm{v} / \mathrm{v})$, and with the carbonized rice husk used in isolation.

Carbonized rice husk is a material of organic origin that has characteristics of low water retention capacity and high porosity. Its use in mixture with expanded clay can result in low density and resistance to particles (Rosa et al., 2012), providing a good water-air ratio (Tab. 1), favoring the root development of $A$. palmatum cuttings.

The mixing of materials with different physical characteristics, such as those used in the present study, most often results in a water retained substrate composition at levels suitable for seedling formation. Similar results were observed in cuttings of Ilex paraguariensis (Brondani et al., 2009), Olea europaea (Oliveira et al., 2009) and Eucalyptus urophylla $\mathrm{x}$ E. grandis (Silva et al., 2012) using different materials in substrate composition, which provided appropriate water retention characteristics.

Materials with adequate balance between porous space and water availability are of fundamental importance at constituting substrates for seedling production, as they favor the best development of plant root system (Tab. 1). Sufficiently porous substrates provide efficient gas exchange and provide greater amounts of oxygen to cuttings, which favors cellular activity during the callus and root formation process (Hartmann et al., 2011). Similarly, water availability directly affects plant development, since water acts on cell expansion and elongation, and therefore on root growth (Claeys and Inzé, 2013; Smirnoff, 2014). Thus, in the production of seedlings, substrates that have adequate levels of water retention and air availability have been used more. However, in the production of cuttings, the use of substrates with low water retention has been prioritized due to the environment remaining with high humidity and requiring irrigation in small intervals of time.

The carbonized rice husk, when solely used provided a high percentage of leaf retention $(95.41 \%)$ in the cuttings of the species under study, not statistically different from its 2:1 (v/v) expanded clay mixture (90.18\%). The positive response of these substrates in the leaf system may have been due to their physical characteristics, since Kratz et al., (2012) point out that the carbonized rice husk combines different grain sizes even in a single material, acquiring adequate physical properties for the good development of the plants.

In view of this, the data obtained in this study show the importance of choosing the adequate substrate and the type of dissolution of the growth regulators to be successful during the production of $A$. palmatum clonal seedlings using herbaceous cuttings. Because these are factors that act directly on the optimization and uniformity during the seedling formation process, under greenhouse and/or nursery con- 
ditions, thus reducing the costs and the production period of the seedlings. In addition, it should be noted that under the conditions in which this experiment was developed, the use of dissolution with $\mathrm{KOH}$ was considered more favorable for the production of clonal seedlings of A. palmatum. Even though there are studies in which the result with hydroalcoholic dissolution also showed satisfactory results for the rooting and survival of cuttings of this species.

\section{Conclusion}

In Acer palmatum cuttings propagation, dissolving indolebutyric acid (IBA) from potassium hydroxide solution $(\mathrm{KOH})$ is more suitable process for rooting. Furthermore, the physical and chemical characteristics provided by substrates formulated from the mixture of carbonized rice husk and expanded clay in volumetric proportions of $1: 2$ and $2: 1(\mathrm{v} / \mathrm{v})$ also provide adequate root development in cuttings of this species.

\section{Acknowledgements and financial support}

The authors report that they received funding and/or support from research incentive institutions. The authors report that there is no conflict of interest in this research or in publishing this manuscript.

\section{Bibliography}

Botin, A.A.; Carvalho, A.; 2015. Reguladores de crescimento na produção de mudas florestais. Revista de Ciências Agroambientais. 13: 83-96.

Brondani, G.E.; Wendling, I.; Araújo, M.A.; Santin, D.; Benedetti, E.L.; Roveda, L.F.; 2009. Composições de substratos e ambientes de enraizamento na estaquia de Ilex paraguariensis A. St.-Hil. Floresta, 39: 41-49. https://doi.org/10.5380/rf.v39i1.13724

Claeys, H.; Inzé, D.; 2013. The agony of choice: how plants balance growth and survival under water-limiting conditions. Plant Physiology, 162: 1768-1779. https://doi.org/10.1104/pp. 113.220921

De boodt, M.; Verdonck, O.; 1972. The physical properties of the substrates in horticulture. Acta horticulturae, 26: 37-44. https://doi.org/10.17660/ActaHortic.1972.26.5

Emer, A.A.; Avrella, E.D.; Fior, C.S.; Schafer, G.; 2019. Nitrogen fertilization for ministrains of Campomanesia aurea $\mathrm{O}$. Berg and its influence on productivity and rooting of minicuttings at different seasons of the year. Revista Brasileira de Ciências Agrárias, 14: e5632. https:// doi.org/10.5039/agraria.v14i2a5632

Emer, A.A.; Avrella, E.D.; Grzeça, G.T.; Luchesse, J.R.; Fior, C.S.; 2016. Produção de mudas clonais de Acer palmatum Thunb por estacas herbáceas. Revista Congrega Urcamp (CD-ROM), 13: 983-992.

Fachinello, J.C.; Hoffmann, A.; Nachtigal, J.C.; 2005. Propagação de plantas frutíferas. Embrapa Informação Tecnológica, Brasília. 
Hartmann, H.T.; Kester, D.E.; Davies, F.T.; Geneve, R.L.; 2011. Plant propagacion: principles and practices. Prentice Hall, New Jersey.

Hoffmann, G.; 1970. Verbindliche methoden zur untersuchung von TKS und gartnerischen erden. Mitteilungen der VSLUFA, 6: 129-153.

Kratz, D.; Wendling, I.; Pires, P.P.; 2012. Miniestaquia de Eucalyptus benthamii x E. dunnii em substratos à base de casca de arroz carbonizada. Scientia Forestalis, 40: 547-556.

Lorenzi, H.; Bacher, L.B.; Torres, M.A.V.; 2018. Árvores e arvoretas exóticas no Brasil: madeireiras, ornamentais e aromáticas. Nova Odessa, São Paulo.

Mahmoud, S.N.; Al-Ani, N.K.; 2016. Effect of different sterilization methods on contamination and viability of nodal segments of Cestrum nocturnum L. International Journal of Research Studies in Biosciences, 4: 4-9. https://doi.org/10.20431/2349-0365.0401002

MAPA - Ministério da Agricultura, Pecuária e Abastecimento. Instrução Normativa n. ${ }^{\circ} 17$, de 21 de maio de 2007. Aprova os Métodos Analíticos Oficiais para Análise de Substratos e Condicionadores de Solos, na forma do Anexo à presente Instrução Normativa. http://ww w.agricultura.gov.br/assuntos/insumos-agropecuarios/insumos-agricolas/fertilizantes/legislacao/in-17-de-21-05-2007-aprova-metodo-substrato.pdf. Acess. november, 6, 2019.

Mews, C.L.; Sousa, J.R.L.; Azevedo, G.T.O.S.; Souza, A.M.; 2015. Efeito do hidrogel e ureia na produção de mudas de Handroanthus ochraceus (Cham.) Mattos. Floresta \& Ambiente, 22: 107-116. https://doi.org/10.1590/2179-8087.080814

Oliveira, A.F.; Chalfun, N.N.J.; Alvarenga, A.A.; Vieira Neto, J.; Pio, R.; Oliveira, D.L.; 2009. Estaquia de oliveira em diferentes épocas, substratos e doses de AIB diluído em $\mathrm{NaOH}$ e álcool. Ciência \& Agrotecnologia, 33: 79-85. https://doi.org/10.1590/S1413-705420090001 00011

Rosa, J.F.V.; Tinôco, I.F.F.; Fernandes, C.M.; Zolnier, S.; 2012. Dimensionamento de painéis porosos para condicionamento do ar em ambientes climatizados. Engenharia na agricultura, 20: 404-411. https://doi.org/10.13083/1414-3984.v20n05a02

Silva, R.B.G.; Simões, D.; Silva, M.R.; 2012. Qualidade de mudas clonais de Eucalyptus urophylla x E. grandis em função do substrato. Revista Brasileira de Engenharia Agrícola e Ambiental, 16: 297-302. https://doi.org/10.1590/S1415-43662012000300010

Simões, D.; Silva, R.B.G.; Silva, M.R.; 2012. Composição do substrato sobre o desenvolvimento, qualidade e custo de produção de mudas de Eucalyptus grandis Hill ex Maiden X Eucalyptus urophylla S.T.Blake. Ciência Florestal, 22: 91-100. https://doi.org/10.5902/1980 50985082

Smirnoff, N.; 2014. Plant stress physiology. In: Els, John Wiley \& Sons, Ltd, Chichester. https:// doi.org/10.1002/9780470015902.a0001297.pub2

Souza, L.S.; Avrella, E.D.; De Campos, S.S.; Fior, C.S.; Schwarz, S.F.; 2018. Clonagem de espécime adulto de Myrcianthes pungens (Berg) Legrand através da estaquia. Iheringia, Série Botânica, 73: 336-341. https://doi.org/10.21826/2446-8231201873310

Stuepp, C.A.; Fragoso, R.O.; Maggioni, R.A.; Latoh, L.P.; Wendling, I.; Zuffellato-Ribas, K.C.; 2016. Ex vitro system for Acer palmatum plants propagation by mini-cuttings technique. Revista Cerne, 22: 355-364. https://doi.org/10.1590/01047760201622032147

Stulzer, G.C.G.; Paula, J.C.B.; Rosalem, I.B.; Pelizzaro, V.; Takahashi, L.S.A.; Faria, R.T.; Koyama, R.; 2018. Enraizamento de estacas foliares de Sedum rubrotinctum (Crassulaceae) submetidas a métodos de aplicação de ácido indol-butírico (AIB) em diferentes concentrações. Revista Terra \& Cultura, 34: 107-116.

Toth, J.; Garrett, P.W.; 1989. Optimum temperature for stratification of several maple species. Tree Planters' Notes, 40: 9-12. 
Vaccari, N.F.S.; Soccol, M.C.H.; Ide, G.M.; 2009. Compostos fenólicos em vinhos e seus efeitos antioxidantes na prevenção de doenças. Revista de Ciências Agroveterinárias, 8: 71-83.

Vignolo, G.K.; Picolotto, L.; Gonçalves, M.A.; Pereira, I.S.; Antunes, L.E.C.; 2014. Presença de folhas no enraizamento de estacas de amoreira-preta. Ciência Rural, 44: 467-472. https:// doi.org/10.1590/S0103-84782014000300013

Yamamoto, L.; Borges, R.S.; Sorace, M.; Rachid, B.F.; Ruas, J.M.F.; Sato, O.; Assis, A.M.; Roberto, S.R.; 2010. Enraizamento de estacas de Psidium guajava L. 'Século XXI' tratadas com ácido indolbutírico veiculado em talco e álcool. Ciência Rural, 40: 1037-1042. https://doi. org/10.1590/S0103-84782010000500006

Zorzeto, T.Q.; Dechen, S.C.F.; Abreu, M.F.; Júnior, F.F.; 2014. Caracterização física de substratos para plantas. Bragantia, 73: 300-311. https://doi.org/10.1590/1678-4499.0086 